\title{
Association between food consumption in the first months of life and socioeconomic status: a longitudinal study
}

\section{Associação entre consumo alimentar nos primeiros \\ meses de vida e condições socioeconômicas: \\ um estudo longitudinal}

\author{
Edson Theodoro dos SANTOS NETO ${ }^{1}$ \\ Carolina Perim de FARIA ${ }^{1}$ \\ Marisa Lyra BARBOSA' \\ Adauto EMMERICH Oliveira' \\ Eliana ZANDONADE ${ }^{1}$
}

A B S T R A C T

\section{Objective}

This paper aims to describe the quality of the feeding practices of infants from the moment liquids and semi-solid foods are introduced into their diets and to determine associations between feeding practices and socioeconomic status.

\section{Methods}

The initial population consisted of 86 infants aged 0 to 3 months; they were selected from 3 Public Primary Healthcare Units of the city of Vitória. Seven visits were made to the children's homes to collect descriptive data on the mother, house, eating habits and sucking habits. Chi-square tests were applied and logistic regression analysis was performed to measure the associations.

\section{Results}

Approximately $50 \%$ of the children were given bottles before age 3 months, while semi-solid foods were given to $75 \%$ of the infants aged 6 months or less. Logistic regression models showed that the lack of paternal contribution to the family's income is a risk factor for the consumption of beans $(\mathrm{OR}=3.9 ; \mathrm{Cl}-95 \%=1.2-12.6)$. Family income equal to or above two minimum wages was likely to promote fruit consumption $(\mathrm{OR}=0.4$ : $\mathrm{Cl}-95 \%=0.14-1.15)$.

\footnotetext{
1 Universidade Federal do Espírito Santo, Centro de Ciências da Saúde, Programa de Pós-Graduação em Saúde Coletiva. Av Marechal Campos, 1468, 29040-090, Vitória, ES, Brasil. Correspondência para/Correspondence to: E.T. SANTOS NETO. E-mail: <edsontheodoro@uol.com.br>.
} 
676 | E.T. SANTOS NETO et al.

\section{Conclusion}

Food variety percentages revealed that most children under two years of age were not being fed properly. The mother's education level and contribution of the father to family income seem to influence the consumption of certain foods, such as fruits and beans. However, they do not fully explain the feeding practices found in the first months of life, showing that other more complex issues may be involved.

Indexing terms: Breast feeding. Weaning. Food habits.

\section{R E S U M O}

\section{Objetivo}

Objetivou-se descrever a qualidade do consumo alimentar de crianças a partir da inclusão da alimentação complementar líquida e semi-sólida, nos primeiros meses de vida, além de determinar as associações entre as práticas alimentares e as condições socioeconômicas.

\section{Métodos}

O grupo inicial constituiu-se por 86 bebês com idades de 0 a 3 meses, selecionados em áreas de abrangência de três Unidades Básicas de Saúde do Município de Vitória (ES). Realizaram-se sete visitas domiciliares, coletando-se dados sobre as características maternas, o padrão de dieta adotado pelas mães e os hábitos de sucção da criança. Os testes de Qui-quadrado foram aplicados e análises de regressão logística foram realizadas para mensurar as associações.

\section{Resultados}

Aproximadamente 50\% iniciaram alimentação complementar por mamadeira até os três meses de vida, enquanto a alimentação complementar semi-sólida até os seis meses de vida ocorreu em $75 \%$ das crianças. Os modelos de regressão logística mostraram que a ausência de participação paterna na renda familiar configura-se como risco para o consumo de feijão $(O R=3,9$ : IC 95\%=1,2-12,6). A renda maior ou igual a dois salários mínimos torna-se potencialmente fator de proteção para o consumo de frutas $(O R=0,4:$ IC 95\% 0,14-1,15).

\section{Conclusão}

Os percentuais de consumo alimentar revelaram a predominância de um padrão inadequado à faixa etária de menores de dois anos. O grau de instrução da mãe e a participação direta do pai na renda da família parecem influenciar nas escolhas de alguns alimentos, como frutas e feijão. Entretanto, não explicam completamente as práticas alimentares infantis nos primeiros meses de vida, sinalizando que outras questões mais complexas podem estar envolvidas.

Termos de indexação: Aleitamento materno. Desmame. Hábitos alimentares.

\section{NTRODUCTION}

Feeding practices during childhood play a fundamental role in growth and overall development of the newborn and is essential for health throughout life. During the first months of life, breast milk is the first and most important food source ${ }^{1}$. Many reasons justify the previous statement, such as, the costs of baby formulas, adequacy of breast milk to the developmental stage of the child, protection granted against infections, allergies and chronic diseases, promotion of mother-child interaction, enhancement of the child's cognitive development, oral health, as well as pos-partum recovery and contraceptive effects on the mother ${ }^{2}$.

Among the 10 steps for correctly feeding children under age 2 years, the Brazilian Health Department lists as the first step the use of breast milk as the only source of nourishment until age six months. Water, teas or any other foods are not to be given. The second step comprises gradual introduction of other types of food while maintaining breastfeeding until age 2 years or more ${ }^{3}$.

A study carried out by Venâncio \& Monteiro ${ }^{4}$ describes that breastfeeding rates have increased during the seventies and eighties; 
another research done by the Brazilian Health Department which included all capitals has shown that the rates of exclusive breastfeeding are still far below the ideal rates recommended by the World Health Organization (WHO $)^{5}$, even after the implementation of new strategies that promote breastfeeding, such as child-friendly hospitals ${ }^{6}$. These rates tend to vary according to the degree of economic development of a country ${ }^{7}$ but the cultural component, which cannot be numerically expressed, seems to play an important role in the introduction of foods other than breast milk ${ }^{8}$.

Breastfeeding patterns can vary from society to society. High-income mothers from developed countries usually breastfeed their children for longer periods than high-income mothers from developing countries; in these countries, low-income mothers are the ones who breastfeed their children the longest ${ }^{9}$.

In this context, bottles are commonly used to supplement liquid intake; the choice of foods usually corresponds to income and the mother's belief of the child's needs; these factors determine the mother's reasons for non-exclusive breastfeeding ${ }^{10-12}$.

Early use of bottles, besides being unnecessary and not recommended, has been found to be the leading factor in the reduction of total breastfeeding duration ${ }^{10,13}$. The commonly used weaning foods are often inappropriate for the child's metabolism and may also carry microorganisms that result in severe infections, especially in the first 6 months of life ${ }^{14}$. Only in exceptional cases, when exclusive breastfeeding is not possible, should infant formulas be used in appropriate cups $^{13}$. The introduction of semi-solid foods commonly known as purées is recommended after the age of 6 months, but parents should focus on the quality of these foods as they are essential for the child's proper growth and development ${ }^{15}$.

Pureed fruits and vegetables are the preferred foods to begin a healthy eating habit, although the determination of these food choices is intrinsically related to cultural and socioeconomic characteristics. Furthermore, after age 6 months, most children start getting their teeth, and chewing begins. According to Torres ${ }^{16}$, both the formation elements and the growth and development of children are intimately related to their nutrition, and to deny it is to deny the essence of life itself.

Given the importance of proper feeding during the first years of life and its repercussion on health, it is critical do determine which weaning foods are commonly used and also the socioeconomic determinants involved in this process. Although apparently simple, a child's food consumption pattern cannot, and should not, be examined under one perspective; a multidisciplinary approach is needed to unveil its complexity.

Thus, the aim of this study is to describe the quality of the diet given to children from the moment supplementary liquids and semi-solid foods are introduced and determine the associations between eating habits and socioeconomic status.

\section{METHODS}

This paper analyzes some of the data from a prospective cohort of newborns followed until age 30 months, all of them living in three suburbs of the city of Vitória (ES). Eighty-six infants aged 0 to 3 months attending three different units of the Programa de Saúde da Familia were included in the sample. These three areas were selected because their infant mortality rates were greater than that of the city (13.5 per 1000 births) in $2001^{17}$.

The sample size was determined by the number of births in the city of Vitória registered in 2001 according to the Brazilian census (www.datasus.gov.br): 4,521 births. In 1999, the breastfeeding prevalence among infants aged 151 to 180 days in the city of Vitória was $74.8 \%(\mathrm{Cl}$ $95.0 \%$ between 72.2 and $76.8 \%)^{18}$. The precision was set at $10.0 \%$ and significance level at $5.0 \%$. The ideal sample size was determined to be 73 children. It was increased by $18.0 \%$ to cover the possible losses, resulting in a sample size of 86 children. All the children indicated by the Programa de Saúde da Família agents were included. Their ages ranged from 0 to 3 months. All children were visited from November 2003 to May 2004. 
During this period, four researchers divided into two teams visited the Primary Healthcare Units and accompanied the Programa de Saúde da Familia agents to visit the children's homes. During the first visit, mothers were given information on baby care practices, oral health, mouth breathing, nutritive and non-nutritive sucking habits, importance of exclusive breastfeeding to age 6 months and non-exclusive from age 6 months to 24 months.

After the information was given, the mothers were asked to participate in this research. All of them were informed about the nature of this study and the periodicity of home visits. All mothers spontaneously agreed to participate and were then interviewed, filled out a form and signed a free and informed consent document.

Home visits took place at set intervals (initially at every 3 months, then every 6 months), when researchers were able to determine if the mothers were following the advice given during the first visit and observe their behavior towards their infant. At every visit, a new form was filled and the infant's mouth was examined. Also, all advice was repeated.

The field work ended in June 2006, totaling 7 home visits per child. The length of the study comprised the duration of breastfeeding recommended by the $\mathrm{WHO}^{5}$, since the children in the sample were on average 29.4 months old (standard deviation 2.5) by the end of the study. The cohort began with 86 children and ended with 67.

This research was approved by the Research Ethics Committee of the Universidade Federal do Espírito Santo, Life Sciences Center, on June 25, 2003, protocol number CEP 0020/2003. All parents signed a free and informed consent form before being enrolled in the study.

Breastfeeding was defined according to the $\mathrm{WHO}^{19}$ as follows:

- Breastfeeding: the child receives breast milk direct from the breast or expressed, consuming or not complementary foods.
- Exclusive breastfeeding: the infant receives only breast milk from the mother or a wet nurse, or expressed breast milk, and no other liquids or solids with the exception of drops or syrups consisting of vitamins, mineral supplements, or medicines.

For the breastfeeding variable to be reported correctly, the mother was asked at every visit if she was breastfeeding the child or using bottles. The mother then informed when the child started being given supplementary liquids or semi-solid foods, stating the commonly used items, such as fruits, vegetables or baby formulas. All the information given by the mother was noted for later assessment.

Once the information was available, it needed to be categorized for analysis, thus the following category variables were created: meats, including fish, pork, beef and chicken; dairy products, such as milk, cheese and yogurt; other protein sources, such as eggs and foods high in soybean proteins; fruits; non-starchy vegetables; high-carbohydrate foods, such as rice, bread, potatoes and pasta; beans; sweets; thickening formulas; caffeine; and added fats.

Socioeconomic variables were collected during the first visit only, because these variables do not usually change over a short period of time. The variables selected for this study were those capable of directly influencing the acquisition of food and food choices. They were: education level of the mother, family income, length of father's employment, number of jobs held by the father, number of jobs held by the mother and marital status of the parents.

Statistical analysis was done with the software Statistical Package for the Social Sciences (SPSS) for Windows, version 11.5. Initially, a descriptive and bivariate analysis was done to associate the socioeconomic and feeding practices variables. The Chi-Square test for dichotomous variables was considered statistically significant when $p<0.05$ and potentially significant when $p<0.10$. The logistic regression analysis then used as dependent variables the consumption of fruits and beans, and as independent variables the 
mother's education level, family income, length of father's employment and father's contribution to family income. All of them had a $p$-value $<0.010$ in the initial analysis. A forward stepwise method (unconditional LR) was used for an automatic selection of variables. A significance level of 0.10 for entering and 0.20 for removing variables in the model was used. The significance level used for variables included in the final model was $p<0.05$.
RES U LTS

Table 1 describes the percentiles that summarize the socioeconomic profile of the sample. Most children were females (53.5\%). The education level of the mothers was considered good since more than $60 \%$ of them studied at least until grade nine. Income was quite homogeneous: the smallest percentiles were found in the lowest income ranges: $15.0 \%$ of the

Table 1. Absolute and relative frequencies regarding the family's socioeconomic profile in the original sample of children aged 0 to 3 months. Vitória (ES), 2003-2006, Brazil.

\begin{tabular}{|c|c|c|c|}
\hline Variable & Categories & Frequency & Percentage \\
\hline \multicolumn{4}{|l|}{ Sex } \\
\hline & Male & 40 & 46.5 \\
\hline Total & & 86 & 100.0 \\
\hline & $9^{\text {th }}$ grade or higher & 52 & 60.5 \\
\hline Total & & 86 & 100.0 \\
\hline \multicolumn{4}{|c|}{ Family Income* } \\
\hline & 0.51 to 1.00 & 13 & 15.1 \\
\hline & 2.50 or more & 18 & 20.9 \\
\hline Total & & 86 & 100.0 \\
\hline \multicolumn{4}{|c|}{ Paternal length of employment } \\
\hline & Less than five years & 53 & 61.6 \\
\hline & Five years or more & 31 & 36.0 \\
\hline Total & & 84 & 97.7 \\
\hline \multicolumn{4}{|c|}{ Number of jobs held by the father } \\
\hline & One job & 63 & 61.6 \\
\hline & More than one job & 3 & 3.5 \\
\hline \multicolumn{4}{|c|}{ Number of jobs held by the mother } \\
\hline & Unemployed & 2 & 2.3 \\
\hline Total & & 86 & 100.0 \\
\hline \multicolumn{4}{|c|}{ Marital status } \\
\hline & Married & 20 & 23.3 \\
\hline & Living together & 40 & 46.5 \\
\hline & Divorced & 26 & 30.2 \\
\hline Total & & 86 & 100.0 \\
\hline
\end{tabular}

*Monthly family income in minimum wages. 
families earned from 0.51 to 1 minimum wage, $22.1 \%$ earned from 1.01 to 1.5 and another $22.1 \%$ earned 2.01 to 2.50 . As for paternal employment, $61.6 \%$ had one job only and most of them had been employed for less than 5 years. Only two mothers were unemployed but it is important to emphasize that, during the research period, most mothers were on maternity leave. Less than half the women (46.5\%) lived with the infant's father and only $23.3 \%$ were legally married.

The box plot graphics in Figure 1 shows the age distribution and the percentiles representing the ages when supplementary foods were introduced. It can be seen that even though the percentages of adequate food consumption is high, their introduction is way too early. Out of the 63 children that started supplementary foods with bottles, approximately $50 \%$ were introduced to bottles before 3 months of age, while $75 \%$ of the 76 children that started supplementary foods with semi-solid foods were introduced to them before age 6 months. These findings are incongruent with the WHO's recommendations, that is, exclusive breastfeeding until the sixth month of life ${ }^{5}$.

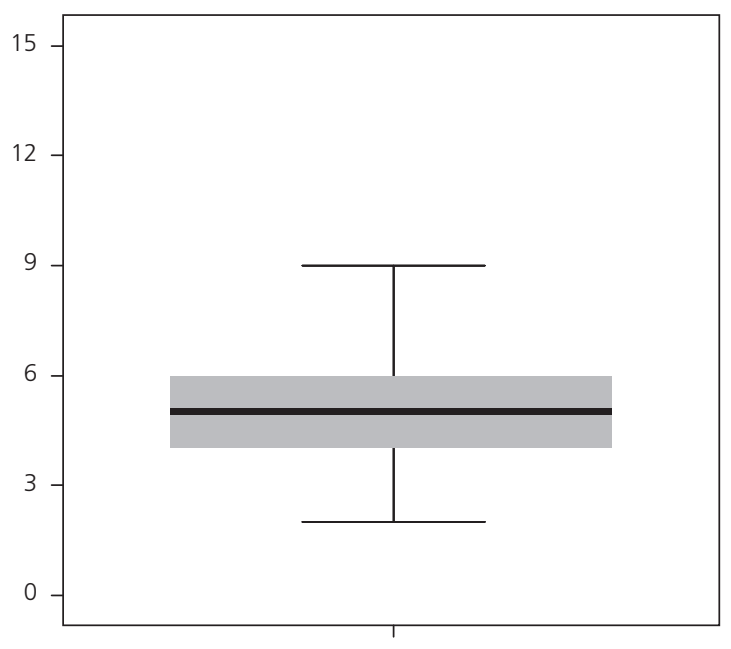

A. Semi-solid alimentary consumption $(n=76)$
Figure 2 shows the food consumption profile of the studied sample. The sample size is 73 because 8 mothers $(9.3 \%)$ said their children ate "everything" without specifying what kinds of foods were commonly offered. Therefore, this information was excluded from the analysis and considered a follow-up loss. This answer could not be used because it might represent the mother's refusal to answer the question properly or inhibition due to being financially unable to provide the child with adequate foods. Five infants were removed from the study sample before information on the introduction of supplementary foods was provided because they could not be found at the informed address.

Meat was consumed by $20.5 \%$ of sample and dairy by $76.7 \%$, while eggs and soybean protein-rich foods by only $4.1 \%$; fruits, non-starchy vegetables, carbohydrates and beans were consumed by $68.5 \%, 75.3 \%, 72.6 \%$ and $54.8 \%$ respectively. Only $4.1 \%$ of the mothers claimed giving foods containing sugar to their children; $68.5 \%$ used thickening formulas and only one mother admitted to giving coffee to her child. None of the mothers claimed to add fat to their child's

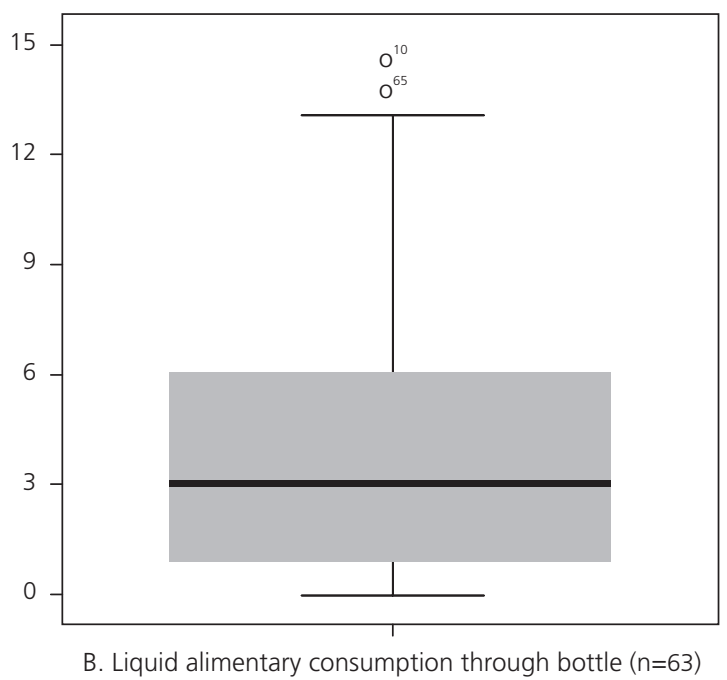

Figure 1. Percentile distribution of the age of introduction of semi-solid foods and liquids through bottles. Vitória (ES), 2003-2006, Brazil. 
food. Yet a reasonable amount of fat could have been added during preparation and not mentioned by the mothers.

In Table 2, Chi-Square tests were used to verify possible associations between food consumption and socioeconomic status. The variables "family income", "marital status" and "number of jobs held by the father" were dichotomized to allow testing and summarize the results. Then each socioeconomic variable was tested against all food consumption variables.

Higher maternal education and family income greater than or equal to 2 minimum wages were likely to be associated with the consumption of fruits. Meanwhile, paternal length of employment greater than 5 years was likely to be associated with the consumption of beans. The father's contribution to family income, whether through formal or informal employment, was significantly associated with greater consumption of beans.

The results of the multiple analysis in Table 3 show that family income equal to or greater than two minimum wages was again likely to be associated with the consumption of fruits $(p<0.10)$, having a statistically significant constant $(p<0.05)$, while the likelihood of consuming beans increased significantly when the father did not contribute to family income.

\section{DISCUSSION}

Approximately $50 \%$ of the sample began supplementary feeding with bottles before age three months. This finding is of great concern because the use of bottles is usually associated with the introduction of foods other than breast milk, going against the recommendations given by the Brazilian Ministério da Saúde and the $\mathrm{WHO}^{3}$. Breastfeeding, in Brazil, is clearly underused ${ }^{18}$; also, early introduction of supplementary foods, either liquid or solid, continues to be one of the most important issues in our public health agenda.

Data presented in Table 3 reinforce this statement by revealing that almost $75 \%$ of the sample was given semi-solid foods known as purees, before 6 months of age. The paper written by Volpini \& Moura20 found similar numbers and

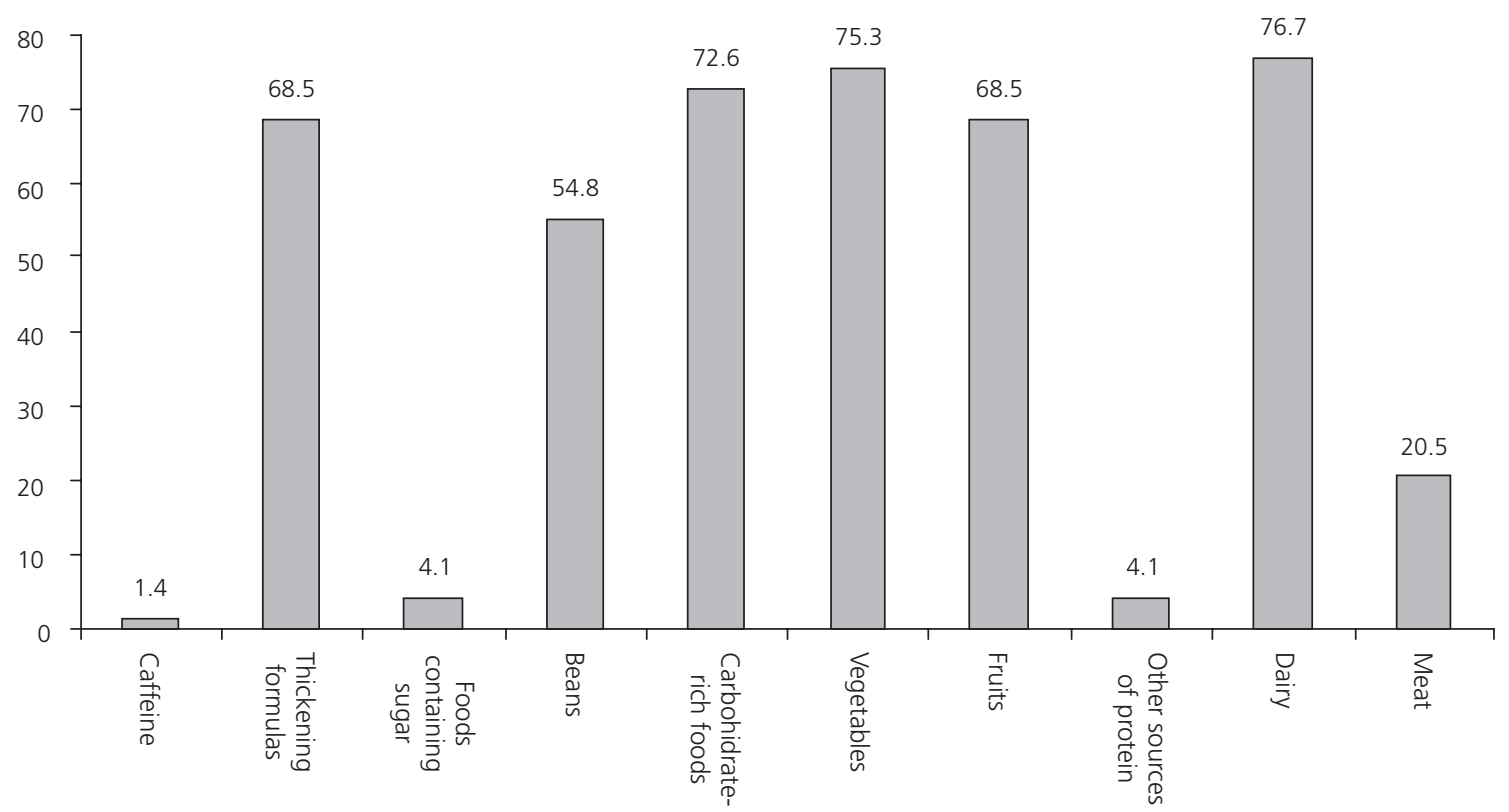

Figure 2. Percentage of consumption of the various food groups during follow-up of the children during their first months of life. Vitória (ES), 2003-2006, Brazil. 
Table 2. Associations between food consumption and socioeconomic variables of children during follow-up. Vitória (ES), 2003-2006, Brazil.

\begin{tabular}{|c|c|c|c|c|c|c|c|}
\hline & \multicolumn{5}{|c|}{ Food consumption } & \multirow{2}{*}{ Chi-Square } & \multirow{2}{*}{$p$-value } \\
\hline & no & $\%$ & yes & $\%$ & Total & & \\
\hline Maternal education level & \multicolumn{5}{|c|}{ Fruits } & & \\
\hline Less than $9^{\text {th }}$ grade & 10 & 23.8 & 32 & 76.2 & 42 & 2.715 & 0.099 \\
\hline $9^{\text {th }}$ grade or higher & 13 & 41.9 & 18 & 58.1 & 31 & & \\
\hline Total & 23 & 31.5 & 50 & 68.5 & 73 & & \\
\hline \multicolumn{8}{|l|}{ Family income } \\
\hline Equal to or more than two minimum wages & 7 & 21.2 & 26 & 78.8 & 33 & 2.958 & 0.085 \\
\hline Less than two minimum wages & 16 & 40.0 & 24 & 60.0 & 40 & & \\
\hline \multirow[t]{2}{*}{ Total } & 23 & 31.5 & 50 & 68.5 & 73 & & \\
\hline & \multicolumn{5}{|c|}{ Beans } & & \\
\hline \multicolumn{8}{|l|}{ Paternal length of employment } \\
\hline Less than five years & 9 & 33.3 & 18 & 66.7 & 27 & 2.719 & 0.099 \\
\hline Five years or more & 24 & 53.3 & 21 & 46.7 & 45 & & \\
\hline Total & 33 & 45.8 & 39 & 54.2 & 72 & & \\
\hline \multicolumn{8}{|l|}{ Father's contribution to family income } \\
\hline Contributes & 12 & 66.7 & 6 & 33.3 & 18 & 4.442 & 0.035 \\
\hline Does not contribute & 21 & 38.2 & 34 & 61.8 & 55 & & \\
\hline Total & 33 & 45.2 & 40 & 54.8 & 73 & & \\
\hline
\end{tabular}

Table 3. Logistic regression modes for the significant associations: consumption of fruits and beans during follow-up. Vitória (ES), 2003-2006, Brazil.

\begin{tabular}{|c|c|c|c|c|c|c|}
\hline \multirow{2}{*}{ Dependent } & \multirow{2}{*}{ Independent variable } & \multirow{2}{*}{ Coefficient } & \multirow{2}{*}{$p$-value } & \multirow{2}{*}{ Odds Ratio } & \multicolumn{2}{|c|}{$\mathrm{Cl} 95 \%$} \\
\hline & & & & & Lower limits & Upper limits \\
\hline \multirow[t]{5}{*}{ Fruits consumption $(+)$} & Family Income* & -0.907 & 0.090 & 0.404 & 0.142 & 1.151 \\
\hline & Equal to or above two minimum & & & & & \\
\hline & wages & & & & & \\
\hline & Constant & 1.312 & 0.002 & & & \\
\hline & Father contributes to family income ${ }^{* *}$ & & & & & \\
\hline Beans consumption (-) & Does not contribute & 1.357 & 0.024 & 3.886 & 1.198 & 12.602 \\
\hline
\end{tabular}

${ }^{*}$ Adjusted by maternal education level; ${ }^{* *}$ Adjusted by paternal length of employment.

also listed the mother's justifications for early weaning: crying after breastfeeding, as if still hungry; the impression of not producing enough breast milk for the child's needs; child rejecting the breast; mother going back to work; pain during breastfeeding resulting from sore nipples and lack of proper guidance.

Many of these justifications could be easily attenuated by better informing the mothers. Mothers tend to cease breastfeeding due to misconceptions and little knowledge of its benefits and techniques, and the civil rights related to breastfeeding. Other topics are not so easy to address and demand the participation not only of the health sector, but also of the society and government, focusing on improving the quality of life and access to education and formal jobs which can provide mothers with the empowerment necessary to fight for their rights.

Only a small percentage of these infants are given meats $(20.5 \%)$ and eggs and soybean protein-rich foods $(4.1 \%)$. Milk is the most importance protein source of their diets $(76.7 \%)$ (Figure 2). Saldiva et al. ${ }^{21}$ found the percentage 
consumption of meats and milk to be $77 \%$ and $36 \%$ in a study done in the city of São Paulo. The low intake of these foods is alarming and leads one to believe that, in this population, calcium intake is impaired in $15.0 \%$ of the children. Iron intake can also be limited because of the small percentage of children eating meats and the high consumption of phytate-rich foods that can impair the absorption of this mineral. Szafarc et al..$^{22}$ stated that iron intake is way below the recommended levels among all children under age two years in Brazil, and is therefore one of the main causes of anemia in the country.

Fruits and non-starchy vegetables are eaten by $68.5 \%$ and $75.3 \%$ of the children respectively; these percentages, although far from the ideal daily intake, is higher than the values found for the general Brazilian population, showing that mothers from this sample are aware of the importance of introducing these items to their child's diets ${ }^{23}$.

The consumption of carbohydrate-rich foods, excluding thickening formulas, is below the amounts expected for this population; also, the intake of beans is quite below the recommendations. These same results have been described as the main trend of the Brazilian nutritional transition ${ }^{23}$. Insufficient bean intake is also considered a risk factor for the onset of anemia in children.

Thickening powders, despite being rich in carbohydrates, deserve to be studied separately since they have a particular meaning when used in children. Its consumption is high since almost $90 \%$ of the mothers give it to their children mixed with milk. Many reasons can be given to justify this practice; among them is the belief that milk does not have enough energy to nourish babies, that other carbohydrate-rich foods commonly consumed by the family are inadequate for the child or that thickening formulas are more appealing to children ${ }^{24,25}$.

It cannot be ignored that most thickening formulas have a high sucrose content which should be used with caution in children. If the consumption of thickening formulas and foods containing sugar were united under the same category, it would reach $72.6 \%$ which is considered high and could lead to high prevalences of obesity and dental cavities $^{25}$.

Only one mother declared giving coffee to her child. None of the mothers declared using fat-rich foods in their child's diet but it is reasonable to assume that some fat may be added to the food during preparation. National studies have found that $34 \%$ of all preparations have added fat ${ }^{26}$. Foods containing sugar may also be underreported by the mothers because they do not consider it good food or because they do not know the nutritional composition of the foods offered to their children.

Two hypothesis can be raised to justify the absence of positive answers when dealing with added fats and foods containing sugar: 1) Mothers intentionally omit the consumption of these items because they are considered unhealthy and answer positively to the consumption of healthy foods even when it does not occur; 2) The second hypothesis is based on the popular saying that real food is "rice, beans and meat", therefore the consumption of fruits, vegetables, fats and sugar are not stated because these items are not real food $^{27}$

Statistical analysis showed potentially significant associations between fruit consumption and higher education levels. The consumption of fruits is generally associated with a higher education level as well as better income, allowing individuals to purchase of such foods ${ }^{21}$. Education is also a determinant of fruit consumption in the sense that it overrules the idea that fruits are not real food and do not provide enough energy and substance to satiate the body, therefore not being an essential dietary item ${ }^{27}$.

Bean consumption was associated with greater length of father's employment and his contribution to family's income, translating into social and financial stability. Women tend to save the best foods for their husbands when meals are taken from home to work, so that his colleagues do not notice financial limitations and to protect the husband from feelings of embarassment ${ }^{27}$. Romanelli27 highlights the importance of women on the family's eating habits, either through 
684 | E.T. SANTOS NETO et al.

preparing or choosing specific foods to be eaten by the whole family. In this study, the absence of paternal contribution to family income was a statistically significant factor for children not eating beans, increasing their likelihood of not eating beans by 3.9 times. This finding could be associated with the fact that beans are considered "a rich food" or nutritious by mothers and therefore they should be provided to fathers because they are the ones that guarantee financial security.

Poulain ${ }^{28}$, quoting Bourdieu, affirms that whatever we eat shows in fact what we are used to eating and what our social class originally ate; our tastes are defined by how much we can spend on food. He also says that eating habits can build a feeling of social adequacy or inadequacy. It is through cooking and table manners that individuals seize social values and networks. The food choices of this study's population picture distinct regional, socioeconomic, cultural, nutritional and psychosocial characteristics, thus creating a sense of limitation by determining what is common concerning local food habits.

The methodological limitations of this study are the following: first, the qualitative analysis of food consumption lacked exact measurements of consumption, thereby preventing the assessment of nutrient adequacy; second, the sample was homogeneous so one cannot expect to find statistically significant differences between variables when the sample population has similar socioeconomic, educational, and living characteristics. Therefore, an association between variables cannot be ruled out. Furthermore, the present findings should not be interpreted as a result of socioeconomic status alone. Food choices must be studied under a broader perspective since there are many other issues influencing the relationship between family dynamics and the newborn child.

\section{CONCLUSION}

Results from this study prove that the eating habits of the sample population do not meet the recommendations given by both national and international health organizations. Socioeconomic status seems to influence food choices to some degree, especially concerning fruits and beans. Among these food groups, no paternal contribution to family income impairs their consumption.

Although the results do not completely explain the phenomenon of childhood feeding in the first years of life, they signal that many more complex issues can be involved. Therefore, there is a strong need for multidimensional researches to assess high risk populations for nutritional excesses, undernutrition, as well as risk factors for improper diets.

This information is crucial for planning public health strategies, which, aided by the general population's effort and interdisciplinary support from the government, may turn breastfeeding and proper feeding of children a reality.

\section{COLLABORATORS}

E.T. SANTOS NETO participated in the design and planning of the study, data collection during home visits, analysis and discussion of the results. C.P. FARIA and M.L. BARBOSA participated in the analysis, interpretation and discussion of the results. A.E. OLIVEIRA participated in the design and planning of the study, supervised data collection during home visits and guided the interpretation of results. E. ZANDONADE participated in the statistical designs of the study and guided the interpretation of the results.

\section{RE FE R E N C E S}

1. Marques Rosa FSV, Lopez Fábio A, Braga Josefina AP. O crescimento de crianças alimentadas com leite materno exclusivo nos primeiros 6 meses de vida. J Pediatr. 2004; 80(2):99-105. doi: 10.1590/ S0021-75572004000200005.

2. Euclydes MP. Nutrição do lactente: base científica para uma alimentação adequada. 2a.ed. Viçosa: UFV; 2000.

3. Brasil. Ministério da Saúde. Dez passos para uma alimentação saudável: guia alimentar para crianças menores de 2 anos. Brasília; 2002.

4. Venâncio SI, Monteiro CA. A tendência da prática da amamentação no Brasil nas décadas de 70 a 80. Rev Bras Epidemiol. 1998; 1(1):40-9. doi: 10.1590/S1415-790X1998000100005. 
5. World Health Organization. The optimal duration of exclusive breast feeding: results of a WHO systematic review. Indian Pediatr. 2001; 38(5): 565-7.

6. Soares MEM, Giugliani ERJ, Braun ML, Salgado ACN, Oliveira AP, Aguiar PR. Uso de chupeta e sua relação com o desmame precoce em população de crianças nascidas em Hospital Amigo da Criança. J Pediatr (Rio de Janeiro). 2003; 79(4):309-16. doi: 10.1590/S0021-75572003000400008.

7. Boerma JT, Rutstein SO, Sommerfelt AE, Bicego GT. Bottle use for Infant Feeding in developing countries: data from the demographic and health surveys. Has the bottle battle been lost? J Trop Pediatr.1991; 37(3):116-20.

8. Kakute PN, Ngum J, Mitchell P, Kroll KA, Forgwei GW, Ngwang LK, et al. Cultural barriers to exclusive breastfeeding by mothers in a rural area of Cameroon, Africa. J Midwifery Women Health. 2005; 50(4):324-8.

9. Victora CG, Barros FC, Vaughan JP. Epidemiologia da desigualdade. 3a. ed. São Paulo: Hucitec; 2006.

10. Audi CAF, Corrêa AMS, Latorre MRDO. Alimentos complementares e fatores associados ao aleitamento materno e ao aleitamento materno exclusivo em lactentes até 12 meses de vida em Itapira, São Paulo, 1999. Rev Bras Saude Mater Infant. 2003; 3(1):85-93. doi: 10.1590/S1519-382 92003000100011.

11. Oliveira LPM, Assis AMO, Gomes GSS, Prado MS, Barreto ML. Duração do aleitamento materno, regime alimentar e fatores associados segundo condições de vida em Salvador, Bahia, Brasil. Cad Saúde Pública. 2005; 21(5):1519-30. doi: 10.1590/ S0102-311X2005000500025.

12. Wayland C. Padrões de amamentação em Rio Branco, Acre, Brasil: um estudo sobre fatores associados com o desmame. Cad Saúde Pública. 2004; 20(6):1757-76. doi: 10.1590/S0102$311 \times 2004000600038$.

13. Howard CR, Howard FM, Lanphear B, Eberly S, Deblieck EA, Oakes D. Randomized clinical trial of pacifier use and bottle-feeding or cupfeeding and their effect on breastfeeding. Pediatrics. 2003; 11(3):511-8.

14. Vieira GO, Silva LR, Vieira TO. Alimentação infantil e morbidade por diarréia. J Pediatr (Rio de Janeiro). 2003; 79(5):449-54. doi: 10.1590/S0021-7557 2003000500013.

15. Monte CMG, Giugliani ERJ. Recomendações para alimentação complementar da criança em aleitamento materno. J Pediatr (Rio de Janeiro). 2004; 80(5):S131-41. doi: 10.1590/S0021-7557 2004000700004.
16. Torres R. Tratado de gnato ortopedia funcional. Buenos Aires: Celcius, 1966.

17. Vitória. Prefeitura de Vitória. Secretaria Municipal de Saúde Plano municipal de saúde. Vitória: Cedoc; 2001.

18. Brasil. Ministério da Saúde. Secretaria de Políticas de Saúde, 1999 [acesso 2006 ago 4]. Disponível em: <http://tabnet.datasus.gov.br/cgi/idb2004/ d20.htm http://tabnet.datasus.gov.br/cgi/idb2004/ d19.htm>.

19. World Health Organization. World Health Organization's infant feeding recommendation. Bull World Health Org. 1995; 73:165-74.

20. Volpini CCA, Moura EC. Determinantes do desmame precoce no distrito noroeste de Campinas. Rev Nutr. 2005; 18(3):311-9. doi: 10.1590/S141552732005000300003.

21. Saldiva SRDM, Escuder MM, Mondini L, Levy RB, Venâncio SI. Práticas alimentares de crianças de 6 a 12 meses e fatores maternos associados. J Pediatr. 2007; 83(1):53-8. doi: 10.1590/S0021-75572007 000100010.

22. Szarfarc SC, Monteiro CA, Meyer M, Tudisco ES, Reis IM. A study of children's health in São Paulo City (Brazil), 1984-1985: X - Food intake. Rev Saúde Pública. 1988; 22(4):266-72. doi: 10.1590/S003489101988000400002.

23. Monteiro CA, Mondini L, Costa RBL. Mudanças na composição e adequação nutricional da dieta familiar nas áreas metropolitanas do Brasil (1988-1996). Rev Saúde Pública. 2000; 34(3):251-8. doi: 10.1590/S0034-89102000000300007.

24. Amador M, Hermelo MP, Peña M. Papel de la pediatria en la prevención de la obesidad y sus efectos sobre la salud. Rev Cubana Pediatr. 1988; 60(6):862-76.

25. Campos FACA, Campos FRA, Cunha Jr. HP, Rocha JA. Etiologia da obesidade em lactentes. J Pediatr. 1985; 58(4):216-20.

26. Farias Jr G, Osório MM. Padrão alimentar de crianças menores de cinco anos. Rev Nutr. 2005; 18(6):793-802. doi: 10.1590/S1415-52732005 000600010.

27. Romanelli G. O significado da alimentação na família: uma visão antropológica. Medicina (Ribeirão Preto). 2006; 39(3):333-9.

28. Poulain JP. Sociologia da alimentação: os comedores e o espaço social alimentar. Santa Catarina: UFSC; 2004.

Received on: 9/10/2007

Final version resubmitted on: 13/8/2008 Approved on: 13/4/2009 